\title{
El obsceno pájaro de la noche: José Donoso y Henry James, la modernidad en diálogo
}

\section{El obsceno pájaro de la noche: José Donoso and Henry James, The Modernity in dialogue}

Laura Judith Becerril Nava Universidad Autónoma del Estado de México

laubn.uaemex@gmail.com

Resumen: En el presente trabajo se analiza El obsceno pájaro de la noche desde el diálogo transtextual entre José Donoso y Henry James Sr. a partir del epígrafe -que corresponde a este último-, de tal manera que la novela donosiana se constituye como simbólica al dar cuenta de la tragedia del hombre moderno, encarnado en la figura del personaje "el Mudito". Como escritores modernos, del romanticismo -James- y de la modernidad hispanoamericana-Donoso-, comparten puntos de encuentro que le permiten al chileno dialogar textualmente con el teólogo, y, más importante aún, transformar sus palabras con una nueva significación. El diálogo, desde la modernidad, muestra la imperfectabilidad del hombre y la consciencia de su fisura ontológica, conflictos que intentan socavarse con James mediante la espiritualidad y la esperanza en la salvación; mientras que Donoso, desde un punto de vista literario, proyecta una realidad descarnada al no poder huir de la tragedia.

Palabras clave: José Donoso, Henry James, El obsceno pájaro de la noche, diálogo, modernidad. 
Abstract: In the present work El obsceno pájaro de la noche is analyzed from the transtextual dialogue between José Donoso and Henry James Sr. from the epigraph of the novel -which corresponds to the latter-, in such a way that it is constituted as symbolic when accounting for the tragedy of modern man, embodied in the figure of the character "el Mudito". As modern writers, of romanticism -James- and of Spanish-American modernity -Donoso-, they share points of contact that allow the Chilean to dialogue with the theologian, and, more importantly, to transform his words with a new meaning. The dialogue, from modernity, shows the imperfectability of man and the awareness of his ontological fissure, conflicts that try to undermine with James through spirituality and hope in salvation; while Donoso, from a literary point of view, projects a stark reality by not being able to flee from tragedy.

Keywords: José Donoso, Henry James, El obsceno pájaro de la noche, Dialogue, Modernity.

Recibido: 22 de abril de 2019

Aceptado: 21 de septiembre de 2019 https://dx.doi.org/10.15174/rv.vi25.457

G 1970 el escritor chileno José Donoso (1924-1996) publicó El obsceno pájaro de la noche, novela que marca el auge de su obra por la abundancia de detalles narrativos, discursivos, temáticos y literarios que sobresalen en cada capítulo que la constituye. De acuerdo con José Promis Ojeda, El obsceno pájaro de la noche constituye el quiebre del orden establecido en las obras anteriores del escritor chileno, en la medida en que "se nos ofrece como el caos, el desorden, [y] la precariedad hechos lenguaje" (Promis, 1973: 189); además, el crítico señala que la importancia del texto radica en la "culminación del proceso creador" de Donoso, ya que 
"es el broche que cierra una etapa, después de la cual sólo cabe cambiar de rumbo" (Promis, 1973: 188).

Proveniente de una "burguesía intelectual", ${ }^{1}$ Donoso es uno de los escritores más importantes a nivel mundial. Su obra ha sido traducida a diversos idiomas como el italiano, portugués, checo, japonés, inglés, entre otros, -la primera traducción se realizó en 1972 al francés-, como muestra de la influencia del chileno en la literatura. Respecto al influjo de su obra, y su gusto por la escritura, él afirmaba:

En Princeton aprendí que la literatura no carecía de glamour, ni era la fuente de culpa y ruina que mi padre me había profetizado me convertirían en un paria, y que por el contrario producía mucho placer. Fui iniciado en la gran pintura del mundo por la que tenía mucho interés y vi esos cuadros con amigos [...] Supe para bien o para mal que era un escritor (Donoso, 1970: 391-395). ${ }^{2}$

Es justamente en la Universidad de Princeton -así como en la Universidad de Iowa- en donde se encuentran diversos manuscri$\operatorname{tos}^{3}$ de Donoso que dan cuenta del proceso creativo de El obsceno

${ }^{1}$ En una entrevista a José Donoso, que realizó un programa de televisión espańola en 1977, a cargo del periodista Joaquín Soler Serrano, Donoso denomina "burguesía intelectual" a su herencia familiar constituida por médicos, abogados y escritores; entre ellos Ricardo Donoso, historiador; Armando Donoso, crítico literario; Heliodoro Yáńez, crítico y escritor, y Fernando Donoso, escritor (Soler, 1977).

${ }^{2}$ La cita fue extraída de la cronología de José Donoso, que se encuentra en la edición de la novela publicada por Ayacucho con prólogo de Hugo Achugar.

${ }^{3}$ De acuerdo con María Laura Bocaz Leiva, el material que cubre desde la década de los años cincuenta hasta 1966 se encuentra en la sección de Colecciones Especiales de la Universidad de Iowa. El material relacionado con la escritura de El obsceno pájaro de la noche comprende 19 cuadernos, los que abarcan principalmente desde el 14 de marzo de 1959 hasta el 5 de diciembre de 1965; por 
pájaro de la noche, la novela que escribió durante ocho años, ${ }^{4}$ periodo en el que experimentó la angustia de la hoja en blanco, el pensamiento vacío y la idea vacilante que surgían por la intención de crear un texto que se desbordaba completamente sin terminar de constituirse; una obra cuya forma es calificada por el mismo autor como "de laberinto, de deterioro, de circularidad, de recurrencia, de suplantaciones" (Donoso, 1971: 530) y que conjuga recuerdos, sueños, pensamientos y alucinaciones.

El obsceno pájaro de la noche ha sido una obra muy estudiada desde diferentes motivos, temas, símbolos y perspectivas; destaco el artículo de Santiago Juan Navarro, intitulado "Locura, monstruosidad y escritura: Hacia un análisis genealógico de El obsceno pájaro de la noche", en el que el autor, partiendo de la noción de genealogía de Foucault, estudia la representación de la locura, lo monstruoso y la función escritural en la novela (Juan, 2016). Por su parte, el estudio de Carmen Martin, "Monstruos y poder en $E l$ obsceno pájaro de la noche de José Donoso", plantea que los seres monstruosos o "marginales", de carácter subalterno y socialmente secundario, poseen una fuente de ilimitado poder al conocer las debilidades de la estructura social (Martin, 2013). Siguiendo esta temática también se encuentra "Poderosos y malignos: el mundo del servicio en El obsceno pájaro de la noche" de María Francisca Ugarte Undurraga, quien analiza la relación ambivalente entre el

su parte, el archivo de la Universidad de Princeton contiene los cuadernos de trabajo a partir de enero de 1966, nueve de los cuales corresponden al proyecto de escritura de El obsceno pájaro de la noche. También incluye correspondencia, versiones mecanografiadas y dos carpetas de fotografías (Bocaz, 2010: 8).

${ }^{4}$ Como se indica en el paratexto de la novela, ésta fue escrita en diferentes etapas: Santa Ana y los Dominicos, Chile, 1962-1963; Pollenca, Mallorca, 1968; Juenga, Santander, 1969, y Vallvidrera, Barcelona, 1969. Cito por la primera edición de la novela publicada por Ayacucho (Donoso, 1970: 385). Anotaré el número de página en el cuerpo del texto. 
mundo del servicio y los patrones, de tal manera que los sirvientes logran la desaparición del mundo para el que trabajan (Ugarte, 2012). A su vez, María Laura Bocaz Leiva, en José Donoso, el Boom y El obsceno pájaro de la noche, realiza un recorrido por el proceso creativo de la novela con base en los manuscritos y diarios del escritor chileno (Bocaz, 2010). Finalmente, y en relación con la temática del presente artículo, "Sobre casas, ventanas y miradas: una cita con José Donoso y Henry James”, de Sebastián Schoennenbeck, quien establece la herencia del escritor anglosajón sobre las obras más sobresalientes del chileno centrándose en los motivos que el título destaca (Schoennenbeck, 2017); entre muchos otros que, sin duda, amplían el panorama crítico de la novela cumbre de la narrativa donosiana.

Uno de los elementos más fascinantes de la novela, y que poco ha llamado la atención de la crítica, ${ }^{5}$ es el epígrafe que encabeza el texto donosiano y que corresponde a Henry James Sr., ${ }^{6}$ paratexto que establece un diálogo entre autores, no sólo a nivel formal, sino de contenido a través de la imagen del Mudito, el personaje princi-

${ }^{5}$ Respecto al estudio del epígrafe puede consultarse el "Prólogo" a la primera edición de la novela (Achugar, 1990); "The Barroque, the Picaresque and El obsceno pájaro de la noche" (Magnarelli, 1981); "Old Women, Orphan Girls and Allegories of the Cave" (Larisch, 1988); "Alguien voló sobre el nido del Bird (un estudio de los manuscritos tempranos de El obsceno pájaro de la noche)" (Rodríguez, 2008).

${ }^{6}$ Me refiero a Henry James Sr. (1811-1882), teólogo estadunidense padre del filósofo Williams James, del novelista Henry James y de la diarista Alice James. La principal característica del pensamiento de James Sr. es que fue seguidor del swedenborgianismo, que fue un movimiento religioso basado en la constitución de una Nueva Iglesia que adoraría a Dios como Jesucristo; por tanto, se puede considerar como un nuevo cristianismo que establecía la negación del naturalismo y la creencia en la revelación divina como medio de salvación. De acuerdo con James sus obras fueron escritas por medio de la inspiración divina, en la que experimentó un acercamiento a la mística cristiana. 
pal; así El obsceno pájaro de la noche se constituye como una novela simbólica ${ }^{7}$ que da cuenta del pensamiento moderno del escritor.

De acuerdo con Gerard Genette, el paratexto es un tipo de relación transtextual que "pone al texto en relación, manifiesta o secreta, con otros textos" (Genette, 1989:10) e indica su correspondencia con títulos, subtítulos, epígrafes, ilustraciones, notas al margen, pies de página, y otros tipos de señales accesorias, autógrafas o alógrafas en el texto (Genette, 1989: 10-12); así, el paratexto en la novela de Donoso recae en el título, el epígrafe y las notas del autor (me refiero a las fechas de escritura de la novela que aparecen al final de El obsceno pájaro de la noche).

Estos tres elementos están intrínsecamente relacionados entre sí al funcionar no sólo como encuadre de la novela, sino que como todo paratexto "procuran un entorno (variable) al texto y a veces un comentario oficial u oficioso" (Genette: 1989: 11-12). Desde esta perspectiva, el paratexto en El obsceno pájaro de la noche tiene la función de configurar una visión de mundo desde la construcción del Mudito como hombre moderno; lectura simbólica guiada por los elementos paratextuales antes mencionados.

El epígrafe con que abre la novela de José Donoso es:

Every man who has reached his intellectual teens begins to suspect that life is no farce; that it is not genteel comedy even; that it flowers and fructifies on the contrary out of the profoundest tragic depth of

\footnotetext{
${ }^{7}$ Entiendo el símbolo desde la teoría de Octavio Paz en la que destaca el carácter metafórico de toda función simbólica. Para el poeta y ensayista mexicano "La esencia del lenguaje es simbólica porque consiste en representar un elemento de la realidad por otro, según ocurre con las metáforas" (Paz, 1972: 34). En este sentido, El obsceno pájaro de la noche es una novela simbólica porque trasciende un solo significado, ya que posiciona al lector entre una multiplicidad de lecturas, imágenes, referencias, diálogos, temas, como muestran los diversos estudios críticos que de ella se han realizado.
} 
the essential dearth in which its subject's roots are plunged. The natural inheritance of every one who is capable of spiritual life is an unsubdued forest where wolf howls and the obscene bird of the night chatters $(81) .^{8}$

Después de estas palabras, el escritor añade: "Henry James Sr., writing to his sons Henry and William" (81). La cita que sirve como epígrafe es el fragmento de una carta que Henry James escribió a sus hijos durante un viaje que realizaron a Europa en 1858.

Con más de un siglo de diferencia, el epígrafe da nombre a $E l$ obsceno pájaro de la noche y de esta manera José Donoso le otorga un nuevo sentido a las palabras de James; ${ }^{9}$ despojándolas de la subjetividad epistolar con que fueron concebidas, crea una novela simbólica del siglo xx al configurar a un personaje que sintetiza al

8 "Cada hombre que ha llegado a su adolescencia intelectual comienza a sospechar que la vida no es una farsa; que ni siquiera es una comedia gentil; que florece y fructifica, por el contrario, en la profundidad trágica más profunda de la escasez esencial en la que se hunden las raíces de su sujeto. La herencia natural de cada uno que es capaz de vida espiritual es un bosque indómito donde aúlla el lobo y el obsceno pájaro de la noche parlotea" (la traducción es mía).

${ }^{9}$ De acuerdo con María Laura Bocaz Leiva no existe una relación directa del epígrafe con el contenido de la novela, ya que fue pensado para el texto una vez que éste se encontraba en proceso creativo. Además, afirma que en las notas de Donoso fechadas hasta 1969 la novela se titula de formas diferentes sin presentar el epígrafe; entonces, según la crítica, fue en los últimos momentos de escritura de El obsceno pájaro de la noche que Donoso decide que la novela se llame así y que lleve la cita de Henry James (Bocaz, 2010: 53-56). Disiento de la autora en cuanto a la inexistente relación directa del epígrafe con la novela, ya que en 1962 Donoso escribe las palabras de James en su libreta -como queda establecido en los manuscritos donosianos-, mientras que la novela se publica en 1970: ocho años tuvo el escritor chileno para interrelacionar su pensamiento con el del teólogo estadunidense, diálogo que establezco en el cuerpo del texto. Respecto a la influencia de James en Donoso véase "Sobre casas, ventanas y miradas: una cita con José Donoso y Henry James” (Schoennenbeck, 2017). 
hombre de la modernidad ${ }^{10}$ desde su función crítica, como estudiaré más adelante.

Entonces, el paratexto de la novela conlleva a otro tipo de relación transtextual ${ }^{11}$ que es la hipertextualidad; es decir, la relación que une un texto B (hipertexto, El obsceno pájaro de la noche) con un texto A (hipotexto, carta de Henry James) en el que se injerta de manera que no es el comentario (Genette, 1989: 14): se puede afirmar, así, que José Donoso toma la cita de James y la transfor$\mathrm{ma}^{12}$ al actualizarla en una realidad distinta que tiene que ver con el contexto latinoamericano y con un momento histórico complejo.

${ }^{10}$ Para efectos del presente estudio importa distinguir entre la modernidad, como fenómeno general adscrito a la cultura occidental, y el modernismo hispanoamericano. Siguiendo a Octavio Paz, la edad moderna es una "edad crítica”, cuyos referentes son la novedad, el cambio, la contradicción, en tanto el hombre interroga y niega la tradición. Además, la época moderna es calificada como anticristiana por la caída de la religión, que permite concebir el inicio de la historia, en este sentido, no hay esperanza ni nuevo origen; para Paz "La modernidad se inicia cuando la conciencia de la oposición entre Dios y Ser, razón y revelación, se muestran como realmente insolubles" (Paz, 2014: 326). Por su parte, en Hispanoamérica surge, a finales del siglo xIx, el modernismo, con influencia de los poetas simbolistas franceses y cercano al romanticismo alemán en temas y formas; destacan los escritores Rubén Darío, José Martí, Manuel Gutiérrez Nájera, Julio Herrera y Reissig. Retomando a Paz, "El modernismo fue nuestro verdadero romanticismo y, como en el caso del simbolismo francés, su versión no fue una repetición, sino una metáfora: otro romanticismo [...] fue no solo la novedad de un lenguaje sino una sensibilidad y una estética impregnadas por la visión analógica de la tradición romántica y ocultista" (Paz, 2014: 366-382; las cursivas son del autor).

${ }^{11}$ De acuerdo con Genette, en un texto pueden converger los distintos tipos de relaciones transtextuales, de manera que otorgan sentido al texto: "no se deben considerar los cinco tipos de transtextualidad como clases estancas, sin comunicación ni entrelazamientos recíprocos. Por el contrario, sus relaciones son numerosas y a menudo decisivas" (Genette, 1989: 17).

${ }^{12}$ Para Genette la hipertextualidad puede derivar por transformación o por imitación. La primera indica que un metatexto habla de un texto al que "evoca 
El proceso transformador sucede al utilizar la cita de James como epígrafe y título de la novela; de esta manera se traslada un texto del romanticismo ${ }^{13}$ a la modernidad, estéticas literarias que comparten puntos de encuentro, pues la primera sugiere una visión de mundo moderna; de acuerdo con Octavio Paz ésta, a propósito de la poesía, inicia a finales del siglo XviıI con el surgimiento

más o menos explícitamente, sin necesariamente hablar de él ni citarlo"; por su parte, la imitación indica un "proceso más complejo [que] exige la constitución previa de un modelo de competencia genérica [...] extraído de esa performance singular [...] y capaz de engendrar un número indefinido de performances miméticas". En resumen: un texto puede ser transformado con un gesto simple y mecánico; mientras que para imitar será necesario adquirir el dominio de aquello que se ha decidido cambiar. Los ejemplos que proporciona al respecto Genette son: el Ulises en relación con La Odisea como una operación transformadora, en la que se transpone la acción de La Odisea al Dublín del siglo xx; mientras que como ejemplo de imitación presenta a La Eneida en relación con La Odisea, ya que Virgilio cuenta una historia distinta, pero inspirándose en Homero -en cuanto a forma y tema- o, mejor dicho, imitando a Homero (Genette, 1989: 14-16).

${ }^{13}$ Me refiero al romanticismo alemán e inglés que surgió en el siglo Xviır, representado sobre todo por escritores como Hölderlin, Blake, Schlegel, Jean-Paul, Novalis, Nerval, poetas revolucionarios que innovaron en la literatura por la inserción de temas como la ironía, la crítica, la transgresión social, el erotismo, la ambigüedad, la imaginación, y, como se verá más adelante, la ruptura, la orfandad, la caída; es decir, la concepción trágica del mundo. No puede confundirse esta estética con el romanticismo hispanoamericano, debido a que éste fue de corte nacionalista con tendencia al subjetivismo sentimental -como el francés y espańol- con autores como Ignacio Manuel Altamirano. De acuerdo con Octavio Paz: "En Francia hubo una literatura romántica - un estilo, una ideología, unos gestos románticos-, pero no hubo realmente un espiritu romántico sino hasta la segunda mitad del siglo xix [...] El romanticismo fue tardío en Espańa y en Hispanoamérica, pero el problema no es meramente cronológico [...] el romanticismo es la otra cara de la modernidad: sus remordimientos, sus delirios, su nostalgia de la palabra encarnada. Ambigüedad romántica: exalta los poderes y facultades del niño, el loco, la mujer, el otro no-racional, pero los exalta desde la modernidad" (Paz, 2014: 368 y ss; las cursivas son del autor). 
del romanticismo: "su nacimiento con los románticos ingleses y alemanes, su metamorfosis en el simbolismo francés y el modernismo hispanoamericano, su culminación y fin en las vanguardias del siglo xx" (Paz, 2014: 325).

En este tenor, Donoso le otorga un sentido específico al epígrafe de James al realizar una transformación semántica mas no formal; $;^{14}$ esto es, las palabras del teólogo en El obsceno pájaro de la noche son exactamente las mismas que en la carta, aunque el significado se altera de un texto a otro, como se verá más adelante.

El título y el epígrafe de El obsceno pájaro de la noche tienen como antecedente las notas de escritura de José Donoso, cuadernos en los que el escritor chileno muestra el proceso creativo de su novela y que también pueden considerarse como paratexto. De acuerdo con Genette "el 'avant-texte' de los borradores, esquemas y proyectos previos de la obra pueden también funcionar como un paratexto" (Genette, 1989: 12).

Por su parte, María Laura Bocaz Leiva realizó un interesante estudio respecto al desarrollo creativo de José Donoso, ya que muestra las "huellas del proceso de escritura de sus obras" (Bocaz, 2010: 19) -notas y manuscritos- plasmadas en los cuadernos de trabajo del escritor chileno. En su texto, José Donoso, el Boom y El obsceno pájaro de la noche, la autora efectúa un recorrido por la escritura donosiana y da testimonio de momentos decisivos en la novela, como el que se refiere al nombre de la misma:

${ }^{14}$ Respecto a la transformación semántica, Genette menciona como ejemplo el caso de Borges al imaginar a Pierre Ménard reescribiendo una nueva versión del Quijote "rigurosamente idéntica en la letra a la de Cervantes, pero a la que dos siglos de historia por medio confieren mayor riqueza y profundidad, y un sentido muy otro; esta apuesta, ya lo he dicho, no es más que una monstruosa extensión del principio de la parodia mínima” (Genette, 1989: 403). 
¿Cómo, cómo diablos hacer calzar "El obsceno pájaro de la noche" con El último Azcoitía? Talvez [sic] buscar algo en "The Ordeal of Richard Feverel", de George Meredith... Ver la posibilidad de hacerlo encajar - por lo menos sacar una frase, para quotation y para título. "Gárgolas" aunque linda palabra, es demasiado obvio y no muy interesante. Revisar de nuevo la posibilidad de ponerle "El oscuro [sic] pájaro de lo noche” ¿Calza? No sé todavía.

No se llamará EL OBSCENO PÁJARO DE LA NOCHE. ${ }^{15}$

-El título que tengo es miserablemente pretencioso (Bocaz, 2010: 54-55).

De acuerdo con las notas de Donoso, el epígrafe fue pensado para la novela una vez que ésta se encontraba en proceso de escritura y tenía por título tentativo "El último Azcoitía", haciendo referencia a la historia de Boy -el hijo de don Jerónimo que vive en la Rinconada, alejado de la sociedad, porque es un ser deforme- ya que con él termina la estirpe aristócrata, pero restándole importancia al Mudito, que en la versión final es el personaje principal.

Bocaz Leiva señala que,

La génesis del epígrafe mediante su transcripción en el cuaderno de trabajo resulta determinante porque es a partir de su consideración que surge la posibilidad de titular a la novela "El obsceno pájaro de la noche", y que se inaugura la lucha de Donoso por lograr hacer calzar su novela con este título que lo seduce (Bocaz, 2010: 54).

${ }^{15}$ De acuerdo con Bocaz Leiva la mayoría de las notas y manuscritos de Donoso muestran erratas en el uso de signos de puntuación, debido a que las escribía para un uso personal sin necesidad de aclaración. Hago énfasis en ello por la ambigüedad en esta cita si se considera la presencia o no de una coma: "No se llamará EL OBSCENO PÁJARO DE LA NOCHE” o "No, se llamará EL OBSCENO PÁJARO DE LA NOCHE" [con mayúsculas en el original]. 
El epígrafe le otorga existencia a la novela como El obsceno pájaro de la noche, así como variadas interpretaciones, ya que fue pensada con variados títulos que al final se englobaron en este; entre ellos: "La agonía de los objetos", "El arcángel incompleto", "Gárgolas", "Palabras de gárgolas", "Bajo tantos párpados", "The Bird”, "El último Azcoitía" ${ }^{16}$ y "El sueño de nadie", ${ }^{17}$ títulos metafóricos que dan cuenta de la multiplicidad en la novela y del simbolismo que la sostiene.

La intención transformadora del epígrafe recae, entonces, en el significado pero no en los acontecimientos: la cita de la carta de James se traslada a un nuevo texto, que es El obsceno pájaro de la noche, y desencadena una lectura que incurre sobre todo en el Mudito, personaje que debe ser interpretado como una figuración metafórica del hombre moderno en tanto vive la tragedia moderna del yo.

En este sentido, el diálogo James-Donoso se establece en la novela desde un fragmento de una carta que muestra la subjetividad del primer autor y su visión de mundo en un momento determinado; palabras que Donoso transforma en su texto para dotarlo de una significación moderna, ya que "todo texto se construye como mosaico de citas, todo texto es absorción y transformación de otro texto. En el lugar de la noción de intersubjetividad se instala la de intertextualidad, y el lenguaje poético se lee, por lo menos, como doble" (Kristeva, 1967: 2; las cursivas son de la autora).

Desde la teoría de Julia Kristeva la intertextualidad es "un cruce de superficies textuales, un diálogo de varias escrituras: del escritor, del destinatario (o del personaje), del contexto cultural actual o

${ }^{16}$ Los distintos nombres tentativos de la novela durante su creación son rescatados por María Laura Bocaz Leiva (2010: 65).

${ }^{17}$ El título tentativo "El sueño de nadie" hace referencia, de acuerdo con Donoso, al epitafio de Rilke (Donoso, 1997: 590). 
anterior" (Kristeva, 1967: 2). En este tenor, la relación intertextual en El obsceno pájaro de la noche ${ }^{18}$ se establece entre el pensamiento de Henry James y José Donoso en un contexto determinado para cada uno de ellos, que muestra la visión de mundo moderna del teólogo y el cuestionamiento donosiano respecto al sentido del hombre en esta época.

La carta de James fue escrita en 1858, en pleno auge del romanticismo; mientras que en el caso de Donoso la cita se actualiza en una realidad diferente en 1970, espacios y tiempos de la modernidad. Nótese la zona de encuentro ${ }^{19}$ entre los dos autores: si bien existe un siglo de distancia entre la carta y El obsceno pájaro de la noche, hay puntos de contacto entre ambas estéticas que permiten resaltar sobre todo la visión de mundo moderna de James en tanto teólogo del romanticismo, pues mientras en su país se seguía la línea romántica -con temas como lo gótico, el vampirismo, el ocultismo, lo sobrenatural-, él hace referencia a una realidad espiritual que no brinda posibilidades de redención, sino que, más bien, da

${ }^{18}$ En el presente trabajo sólo hago hincapié en el diálogo intertextual de José Donoso con Henry James desde el epígrafe; sin embargo, en la novela el diálogo se extiende a la mitología mapuche, la historia oficial chilena y latinoamericana, entre muchas otras relaciones textuales. Véase "La bruja y la ruptura de un orden en El obsceno pájaro de la noche de José Donoso" (Schoennenbeck, 2009); "El desdibujamiento de la Peta Ponce: otra clave inédita del delirio" (Bocaz Leiva, 2005); Historia personal del Boom (Donoso, 1972); "José Donoso: perversión y espacio social en la narrativa chilena” (Inostroza, 2013).

${ }^{19}$ Siguiendo a Rafael Argullol, "Uno de los errores más vulgares, pero más comunes, es decir ‘romántico〉 y pensar (pasado), cuando en realidad el pensamiento romántico es una contundente diagnosis de futuro. En la insuperable combinación de desencanto y energía, de destrucción y de innovación, de patetismo y de heroicidad, en la profunda percepción de lo limitado de la condición humana y en el imposible titanismo hacia lo infinito, se puede reconocer que el movimiento romántico es la auténtica raíz de todo el pensamiento trágico moderno" (Argullol, 2008: 54; las cursivas son del autor). 
cuenta de la tragedia del hombre al tomar consciencia intelectual de su imperfectibilidad.

El romanticismo sugirió un pensamiento moderno cuando reflexionó sobre la heroicidad del hombre, y el "yo", entonces, se convirtió en el eje de la literatura y desde la subjetividad se hablaba de la objetividad; en este sentido, los poetas románticos -sobre todo los ingleses y alemanes- marcaron una clara diferencia de los movimientos literarios anteriores al escribir sobre la voluntad heroica de lo ilimitado; es decir, sobre la tragedia moderna del yo, ${ }^{20}$ que simbólicamente hace referencia a la herida del hombre al saberse escindido por la ausencia de Absolutos.

Esta ausencia, o "escasez" como la denomina James, indica la concepción trágica del mundo, debido a que desaparece la noción de divinidad que acompañó al hombre del renacimiento; esto es, mueren los dioses que dirigían su destino y, ante esta situación, se presenta la travesía del yo, o "el viaje” que menciona el teólogo.

${ }^{20}$ En el romanticismo una de las imágenes más importantes fue la del hombre como héroe, en la medida en que sus acciones tenían la finalidad de alcanzar la trascendencia, la gloria o el poder; es el caso de Aquiles, el gran modelo trágicoheroico de la Antigüedad de acuerdo con Hölderlin, ya que "Irremediablemente condenado a morir en edad joven por un funesto designio del más allá, se enfrenta con su destino, con un ideal audaz y blasfemante desafía la sentencia de los dioses [...] acepta el dolor, el desprecio de la resignación, el anhelo de la profundidad y de la acción” para alcanzar la gloria (Argullol, 2008: 92-93). En este sentido, el Mudito no puede interpretarse simbólicamente como héroe, porque en la novela se posiciona como hombre moderno en la medida en que es consciente de su finitud, intrascendencia y orfandad. Si bien el Mudito tiene el impulso por ser alguien más, no lo logra más que mediante la imaginación; se podría hablar, entonces, de una "heroicidad ensoñada", en la que sí llega a ser otro y trasciende su propia historia; sin embargo, no es real su apellido, su profesión ni su posición social e intelectual; él es, en realidad, un hombre sujeto a su contingencia histórica. Su heroicidad, desde este punto de vista, es ambigua, ya que la alcanza únicamente en los mundos posibles imaginados, por tanto, su tragedia se desarrolla en ámbitos cotidianos, seculares, humanos. 
En este contexto, el individuo toma consciencia de la anulación del Único y se concibe como hombre en constante lucha consigo mismo; así, ya no busca la síntesis, sino que se erige como sujeto consciente de los límites humanos: de su mortalidad, ésta es la tragedia del yo romántico, el saberse escindido por la muerte de Dios, finito e imperfecto. De acuerdo con Argullol, el hombre "tiene muy presente la conciencia dolorosa, trágica, de la contradicción entre el Yo y el Infinito, así como la necesidad de una reconciliación mitica: conciencia y necesidad de reconciliación que hacen que el Yo Trágico se superponga al Yo Absoluto" (Argullol, 2008: 71; las cursivas son del autor).

La necesidad de sutura indica la búsqueda del retorno a la Edad de Oro; es decir, al paraíso cristiano en el que el Yo heroico se fusiona con el Único para alcanzar la gloria, el infinito o la trascendencia; sin embargo, esta comunión sólo puede ser simbólica, ya que el hombre moderno ha experimentado la caída y está "sumido por la irremediable ley que rige el destino de los hombres a un ostracismo sin retorno" (Argullol, 2008: 80).

La gran herida originaria, la fisura, misma que separa al hombre de Dios, pero también de la naturaleza y del otro, indica que el sujeto se sabe huérfano y sin referentes, porque no hay sutura que borre definitivamente las huellas de la separación. Patxy Lanceros, en La herida trágica, afirma que,

Estos tres elementos, que el proceso occidental de civilización ha separado progresivamente, constituyen, en los primeros estratos de la humanidad, los tres rostros solidarios de una misma figura: el Dios, el Hombre, la Naturaleza, trinidad primigenia (preludio de toda trinidad ulterior), evocación permanente de la totalidad escindida, de la herida trágica, del sentido fragmentado y roto (Lanceros, 1997: 46). 
La finitud del hombre, simbolizada por la caída, lo configura como huérfano, vacío, angustiado y sin referentes ante la quiebra de la religión. De acuerdo con Octavio Paz, la caída implica una gran paradoja, ya que la orfandad del hombre indica que es hijo del limo, pero no hay un creador; entonces, "no es el mundo caído de la mano de Dios, el que se precipita en la Nada, sino que es Dios el que cae en el hoyo de la muerte" (Paz, 2014: 342).

Ante la inexistencia de un orden divino o natural que regule el mundo, el hombre se somete al caos, al abismo y a la nada, entonces, no tiene aliento más que su propio ser para reencontrarse; de ahí la creación en literatura de mundos posibles, la transgresión, el artificio, la crítica como recursos para intentar la sutura simbólica.

Esta idea romántica del hombre es la que guía el pensamiento de Henry James, quien en la carta manifiesta "una concepción paterna acerca de la verdad de la vida, [y] comienza estableciendo que la vida no es una farsa ni siquiera una gentil comedia, o sea que no es una representación amable de una realidad" (Achugar, 1990: XXVI; las cursivas son del autor). En este sentido, para el teólogo la realidad es trágica cuando el sujeto alcanza su plenitud en la escasez; es decir, se sabe imperfecto.

James agrega que la herencia del individuo es un bosque indómito donde aúlla el lobo y el obsceno pájaro de la noche parlotea: legado natural de todo sujeto espiritual que, según su pensamiento teológico, se produce mediante la separación de Dios con la naturaleza o de la naturaleza con la realidad; así, para James la realidad es meramente espiritual, de tal manera que el hombre apenas puede comprenderla, por eso la configura como un bosque indomable en el que se conjugan el aullido del lobo y el parloteo o canto del pájaro nocturno. Desde la interpretación de Hugo Achugar, la selva es el universo libre de la imaginación, donde sus habitantes emiten su sonido y construyen un discurso (Achugar, 1990: XXVI). 
A su vez, James parte del viaje, que más que traslado indica madurez para comprender que la vida no es ni comedia, ni farsa, sino imperfecta, finita, trágica. Y es trágica, justamente porque, en el plano espiritual que podría representar trascendencia, se conjugan el instinto y la obscenidad, el aullido y el parloteo, el lobo y el pájaro nocturno; elementos que remiten a las tinieblas, al pronto amanecer que no llega y que se acompańa por sonidos repulsivos, siniestros, blasfemos. ${ }^{21}$

Aunque se podría considerar una visión negativa de la realidad en la cita de James, no es del todo así, ya que en medio de los elementos que implican oscuridad, caos y aullido, "florece y fructifica" la vida, que, si bien es trágica, implica la existencia del sujeto y, por ende, su posible salvación desde la espiritualidad.

La noción de ruptura de James es retomada por Donoso en El obsceno pájaro de la noche, y en este tenor el epígrafe guía la

${ }^{21}$ El vocablo latino obscenus ha adquirido la significación moderna de indecente, sin pudor o que ofende a los sentidos; sin embargo, en su origen latino denota lo siniestro, de mal augurio, blasfemo, algo terrible y que por tanto no gusta (López, 1997). Siguiendo a Sebastián Schoennenbech, el término "obsceno" también hace referencia a un "estar fuera de escena" (2017: 529), en la medida en que el Mudito, que se hace acompañar únicamente de su soledad en la Casa de la Chimba, es un ser des-socializado, ya que rompe el vínculo con el mundo exterior; muestra de ello es su estadía en el cuarto-sótano o en los diferentes rincones del exconvento, en los que vive su tragedia sin enmascaramientos o disfraces, sin ocultar o aparentar ser otro. De acuerdo con Schoennenbech, "el sujeto se des-socializa, perdiendo su vínculo con el mundo de afuera. Su ciudadanía se vuelve un exilio en el que se contempla el silencio de los objetos rechazados por el orden actual. La intimidad de esta casa no sólo radica en la soledad de quien la habita, sino también en el diálogo secreto del coleccionista y sus cosas, ya que el primero también se vuelve un objeto de la mirada de sus bibelots y retratos. Es esta relación recíproca, íntima y desconcertante la que Donoso revela descarnadamente, transformando ese espacio original en una representación obscena. Aquella intimidad -que por ser tal estaba fuera de escena- es ahora develada" (2017: 529). 
lectura de la novela desde una concepción trágica del mundo del Mudito, ${ }^{22}$ el personaje que simboliza al hombre moderno, quien por su inherente capacidad crítica $^{23}$ y reflexiva -intelectual-, ha tomado conciencia de que la vida no es una farsa ni una comedia, ni risa ni llanto; sino que -florece y fructifica- en el seno de la profunda tragedia moderna, en un contexto en el que se sabe escindido, sin fundamentos, sin referentes. El Mudito afirma citando a su padre: "No, no, Humberto, hay que respetar el orden, no se puede engañar ni robar, para ser caballero hay que empezar por ser honrado. No podemos ser Azcoitía. Ni siquiera tocarlos. Somos Peńaloza” (120).

Pese a los diferentes intentos del Mudito por adquirir el apellido Azcoitía o relacionarse con la familia aristócrata -haciendo

22 El Mudito vive en la Casa de Ejercicios Espirituales de Encarnación de la Chimba, en Chile, un ex convento en el que habita con algunas viejas sirvientas, huérfanas y una monja. Él se encarga de la limpieza del lugar y, sobre todo, de mantener el control de la puerta; motivo por el que se considera un carcelero con total poder sobre las prisioneras. Al ser el único hombre de la Casa, él es el responsable de ayudar a las viejas y a la Madre Benita, su mentora. Desde sus propias palabras, el Mudito da cuenta de su historia, misma en la que resalta la ambigüedad de su veracidad: hijo de un profesor de primaria, que a su vez fue hijo de un maquinista de locomotora y cuyo nombre era Humberto Peñaloza, el mismo que el del Mudito y, por tanto, su única herencia basada en el determinismo. Hijo de una costurera que le enseñó su lugar en el mundo, el bajo, el del servicio. Ante este panorama, sin posibilidades de ascenso, el Mudito recurre a la imaginación, el sueño, las alucinaciones y la representación para crear mundos hipotéticos en los que es escritor, secretario particular de un senador-Jerónimo de Azcoitía-, amante de Iris e Inés, administrador de la Rinconada, entre otros en los que logra configurarse como un hombre con nombre y apellido en el mismo nivel que los del mundo de lo alto.

${ }^{23}$ Para Octavio Paz, la crítica es una de las principales características de la época moderna, que marca el carácter reflexivo del hombre en relación consigo mismo, con el otro y con el entorno; de modo que adquiere la capacidad intelectual de cuestionar, examinar y, en esta medida, formar su propia concepción de la realidad. 
pasar al hijo que engendró con Iris como de don Jerónimo, ser el secretario particular y consejero del gobernador Azcoitía, procrear a Boy con Inés-Peta ${ }^{24}$ y erigirlo como el último de la estirpe noble-, éste es consciente de que los mundos posibles en los que sucede tal trato son exactamente eso, universos imaginarios que le brindan satisfacción y felicidad, pero que en realidad no existen.

El Mudito es el personaje de la novela quien, por un lado, desea la Edad de $\mathrm{Oro}^{25}$ a la que accede mediante su discurso en la creación de mundos posibles; pero que, por el otro, no puede huir de su realidad porque ésta lo avasalla: le impide alcanzar la completitud. En esta medida, él es consciente de la escisión y ya no busca la unidad, sino que constantemente se reafirma en un "Yo soy"; por ejemplo, "Yo soy el padre del hijo de Iris (127), "Soy escritor" (266) , "Soy la séptima vieja (146)" 26.

${ }^{24}$ En uno de los mundos posibles del Mudito, éste mantiene relaciones sexuales con Inés de Azcoitía y conciben a Boy, niño-monstruo del que Jerónimo se hará responsable por creerlo su hijo. Sin embargo, al tratarse de un mundo imaginado, el Mudito plantea que Inés, mediante la inversión de roles, es en realidad la bruja Peta Ponce, de tal manera que ha fornicado con la mujer de manos verrugosas y no con su amada.

${ }^{25}$ El retorno a la Edad de Oro, con la mirada hacia atrás, es imposible para el Mudito, ya que no existe para él, pues no tiene origen, historia ni pasado; entonces, busca crear un mejor porvenir imaginado en el que resalta su ascenso social, su "disfraz de caballero" (132) y su apellido; además, se configura como un gran escritor e intelectual de la época.

${ }^{26}$ Los tres ejemplos corresponden a diferentes funciones del Mudito en la novela, de tal manera que se configura como un personaje múltiple y fluctuante. Como padre del hijo de Iris, una de las niñas huérfanas de la casa, el Mudito reafirma su virilidad y, a su vez, enfatiza la impotencia sexual de Jerónimo para concebir un hijo. Por su parte, como escritor, uno de sus principales roles, el Mudito adquiere identidad, un nombre y una profesión. Finalmente, "la séptima vieja" corresponde al Mudito en su transformación femenina, quien asimila las características de las viejas de la Casa en relación con la tradición, la oralidad y la mitología. 


\section{De acuerdo con Rafael Argullol,}

La actitud trágico-heroica [...] significa, desde luego, el rechazo de la resignación y la impotencia ante la imposibilidad del Infinito, es decir, de la plenitud. Significa aceptar con violencia la violenta escisión que dicha imposibilidad provoca, permanentemente, en la conciencia del hombre. Significa aceptar una concepción trágica de la vida frente a la tragedia de la vida (Argullol, 2008: 89; las cursivas son del autor).

La "profundidad trágica" del hombre moderno -la conciencia de lo inalcanzable- acaece en el "indómito bosque", en el espacio que es todo y nada, caos y silencio, ante la presencia de la muerte, en donde "el lobo aúlla y el obsceno pájaro de la noche parlotea". De la misma manera que James, Donoso retoma la simbología del pájaro y del lobo, ${ }^{27}$ ése como ave de las tinieblas y éste como el instinto del hombre, cuya conjunción sintetiza "la voz triste y prolongada del lobo" (RAE, 2006) y el parloteo ${ }^{28}$ del pájaro nocturno.

Además, desde la mitología mapuche, que en El obsceno pájaro de la noche se hace presente en los diferentes niveles textuales, el Mudito se constituye como chonchon y como imbunche, ${ }^{29}$

${ }^{27}$ De acuerdo con Hal Foster, desde una concepción psicoanalítica de "El hombre de los lobos" de Freud, el lobo es un animal ambivalente y primitivo en la medida en que da cuenta de la identidad sexual del hombre y de una subjetividad masculina relacionada con el padre (Foster, 2008: 23).

${ }^{28}$ Según la RAE, el parloteo es propio de algunas aves que hacen sonidos semejantes a la locución humana (RAE, 2006).

${ }^{29}$ El choñchoñ era un ser constituido por cabeza con alas, y representaba la transformación de los brujos para efectuar sus peregrinaciones nocturnas. Para hacer sus salidas, los brujos desprendían la cabeza del cuerpo y las orejas se transformaban en alas. El cuerpo, durante la ausencia de la cabeza, debía quedarse de espaldas, ya que de otro modo no podría reunírsele a su vuelta. El grito de esta ave era considerado como anuncio de muerte próxima (Espósito, 2003: 
símbolos de la tradición chilena que muestran la visión popular en la novela basada en la brujería, los rituales, lo no oficial.

Así, en diálogo con la novela, el Mudito, por su capacidad crítica, creativa, reconoce su mortalidad y en el abismo de lo indeterminado coexiste con las viejas en espacios en su mayoría cerrados, ocultos, oscuros, nocturnos; mujeres que se configuran como lobos, cuya voz triste lamenta la soledad, el olvido, la desesperanza. A ellas se une el Mudito con su canto, en tanto pájaro, -irónicamente, por su sobrenombre-, para crear mundos posibles a partir de la imaginación.

Nótese que el epígrafe proyecta a un pájaro que parlotea, que charla: humanización del ave que revela la figura del Mudito como voz que narra los acontecimientos y que dialoga con los otros personajes; diálogo que se efectúa desde el fluir de la conciencia, la ensoñación, la alucinación y el mismo silencio.

Por otra parte, obsérvese al respecto que James proyecta a un pájaro nocturno que parlotea, haciendo referencia a un ave nocturna que anuncia las tinieblas; mientras que el simbolismo del pájaro en Donoso detona múltiples significaciones por la conexión

288). Esta significación es la que se retoma en El obsceno pájaro de la noche: "se decía que decían o que alguien había oído decir quién sabe dónde que en las noches de luna volaba por el aire una cabeza terrible, arrastrando una larguísima cabellera color trigo [...] cantaba el pavoroso tué, tué, tué de los chonchones, brujería, maleficio, por eso las desgracias incontables, la miseria que ahogaba a los campesinos" (95). En ivunche es un ser mitológico representado en forma de niño hinchado, con una pierna adosada a la nuca y la cabeza vuelta hacia atrás. Camina en tres patas y con un bastón. No habla, sólo emite sonidos guturales. Los brujos lo utilizan para sus hechicerías. Los ivunche van desnudos y sólo salen de sus cuevas acompañados por los brujos (Espósito, 2003: 292; las cursivas son mías). En la novela el Mudito se compara con un imbunche y, evidentemente, las viejas son las brujas que lo acompañan: "Así es la única manera de criar a un niño para que sea santo [...] El imbunche. Todo cosido, los ojos, la boca, el culo, el sexo, las narices, los oídos, las manos, las piernas" (110). 
en la novela con la mitología mapuche, lo grotesco, la ensoñación, la alucinación y demás recursos narrativos que posibilitan diversas lecturas; el Mudito es, entonces, ave, gárgola, arcángel, testigo y creador.

Como ave, el Mudito es quien habla, es el ser que debería permanecer en silencio, pero que "revela y dice lo que se debe callar o lo que no hay necesidad que se sepa" (RAE, 2006). Además, como pájaro el Mudito conecta el cielo con la tierra, la imaginación con la realidad, la historia con la mitología. Para Hugo Achugar, refiriéndose a la presencia del pájaro en toda la obra de Donoso:

Se trataba de la imagen de un animal, calificado en cada caso como "extraño", "fantástico", "monstruoso", que describía la fusión de cuerpos humanos en combate [...] ese animal era "concebido por el poder de la imaginación como emblema de una libertad que a imagen de Hydra tiene todas las cabezas posibles y que representa el terror y la angustia del ingreso a una zona donde todo se transforma y nada es seguro. Emblema de la imaginación, concentra todo el espanto que la ambigüedad trae consigo cuando se anula la realidad cotidiana y simple y se pierden sus limites" (Achugar, 1990: XXVI; las cursivas son mías).

El Mudito nunca ha salido de la Casa, ${ }^{30}$ así lo afirman las viejas, pero no lo hace como hombre, sino como ave, como el obsceno pájaro que en la noche, como voyeur, observa, contempla, vigila: se convierte en un ave para hacerlo, de ahí la importancia de la mirada en la novela y de la mitología mapuche.

Algunos estudios críticos que se centran en el epígrafe coinciden en la noción trágica del hombre moderno; sin embargo, no

${ }^{30}$ Respeto la tipografía de la novela. 
ahondan en ello. De acuerdo con Waldemar Verdugo Fuentes en una entrevista a Donoso:

\begin{abstract}
"El obsceno pájaro de la noche", la novela más traducida de José Donoso es, según el epígrafe de Henry James que encabeza la obra, el ave que canta en ese trágico bosque de tinieblas que todos llevamos dentro [...] En ese lugar donde la gente no importa, en ese reino de desencanto es donde grazna el obsceno pájaro de la noche (Verdugo, 2018: 1309).
\end{abstract}

En esta referencia se resalta la interioridad del yo y la tragedia moderna, pues muestra la indeterminación del hombre en la modernidad ante la pérdida de referentes y el encuentro insignificante con el otro. Además, siguiendo la línea romántica, Miguel Ángel Náter comenta:

Es evidente el romanticismo del fragmento [...] La esencia del pájaro, ya sea el cuco de William Wordsworth o ya sea el ruiseñor de John Keats, refiere la búsqueda nostálgica en la de un bosque simbólico que representa el cosmos y el microcosmos. El contacto romántico con la naturaleza debería producir el estado paradisíaco [...] Sin embargo, contrario a esa poética esperanzadora e idealizadora del romanticismo, Donoso modula una siniestra alegoría en la cual el bosque corresponde a la conciencia, mientras los temores que la atormentan serían representados mediante el lobo que aúlla y el obsceno pájaro de la noche que ulula en lo profundo del bosque nocturno (Náter, 2007: 24).

El romanticismo-modernidad que sobresale del epígrafe está concentrado en la imagen del Mudito: la nostalgia, lo siniestro, el bosque nocturno son elementos fusionados que representan el estado del personaje moderno en el que se hunde cada vez más, pero 
del que intenta huir mediante el ensueño, el inconsciente, la alucinación: "La realidad, entonces, es una mezcla entre lo espiritual y lo instintivo, la imaginación sin límites y el mundo mensurable de lo cotidiano" (Santini, 2001: 232).

El Mudito es un hombre moderno sin identidad, ya que es un ser fragmentado, escindido, herido y solo en el mundo. Su principal sentimiento es la melancolía, herencia de un padre que únicamente le enseñó a desear el mundo del otro mediante el ascenso social, el disfraz de caballero y una profesión; a ser, en pocas palabras, como don Jerónimo de Azcoitía, símbolo de la perfección terrenal:

De pronto mi padre me dio un tirón de la mano. Yo seguí la dirección de esa mirada suya a la que unía la mía. Por la vereda avanzaba entre el gentío alegre de esa mañana un hombre alto, fornido pero gracioso, de cabello muy rubio, de mirada airosa encubierta por algo que yo interpreté como un elegante desdén, vestido como jamás soñé que ningún hombre osara vestir [...] Entonces, al mirarlo a usted, don Jerónimo, un boquete de hambre se abrió en mí y por él quise huir de mi propio cuerpo enclenque para incorporarme al cuerpo de ese hombre que iba pasando [...] Seguimos camino sólo porque no podríamos quedarnos parados ahí, contemplándolo para siempre, que es lo que él y yo queríamos. Mi padre suspiró. Tan cerca de nosotros que había pasado (133).

Don Jerónimo es un caballero, aristócrata y político, que representa al hombre ideal desde la visión del Mudito. Éste permanece en la memoria del protagonista desde la primera vez que lo vio; no lo olvida porque él reafirma la necesidad de Humberto Peńaloza padre de "pertenecer a algo distinto a ese vacío de nuestra triste familia sin historia ni tradiciones ni rituales ni recuerdos" (130). Don Jerónimo será, en este sentido, quien reafirme la tragedia del 
Mudito: esa imposibilidad de llegar a ser alguien porque, desde el nacimiento, está determinado a una realidad que lo somete al mundo de lo bajo, de la suciedad, del anhelo y del olvido.

En tanto símbolo del hombre moderno, el Mudito es consciente de su orfandad: por un lado, su padre murió y su única herencia fue la nostalgia; y, por el otro, sabe que Dios no existe. Respecto a su padre afirma:

Somos Peñaloza, un apellido feo, vulgar, apellido que los sainetes usan como chiste chabacano, símbolo de la ordinariez irremediable que reviste al personaje ridículo, sellándolo para siempre dentro de la prisión del apellido plebeyo que fue la herencia de mi padre. Porque tuve padre, don Jerónimo, sí, aunque usted no lo crea, aunque jamás se preocupó por investigar ni preguntarme sobre ese hecho innegable, yo tuve padre, y tuve madre, y tuve una pobre hermana (129).

La fisura del Mudito le brinda la posibilidad de sutura simbólica mediante la creación de mundos hipotéticos en los que logra el ascenso social que su padre anhelaba. En ellos se convierte en secretario particular del senador Jerónimo de Azcoitía, en un escritor reconocido y en el administrador de la Rinconada, donde vive el hijo de Inés y Jerónimo; universos en los que logra desarrollarse plenamente, pero que paradójicamente sólo existen en su imaginación.

De esta manera, el Mudito es un personaje abyecto que se resguarda en un sótano o en un rincón y sólo sale para cumplir sus funciones como sirviente; pero que, al mismo tiempo, se eleva mediante la imaginación y logra ser una gárgola, un ave o un arcángel que contempla el abismo de una realidad sin creador: 
Yo no entiendo, Madre Benita, cómo usted puede seguir creyendo en un Dios mezquino, que fabricó tan pocas máscaras, somos tantos los que nos quedamos recogiendo de aquí y de allá cualquier desperdicio con que disfrazarnos para tener la sensación de que somos alguien, ser alguien, gente conocida, reproducción fotográfica en el diario y el nombre debajo, aquí nos conocemos todos, en realidad casi todos somos parientes (162).

La necesidad de crecimiento y ascenso del Mudito lo hace consciente de su realidad, una realidad que pareciera los demás habitantes de la Casa no ven, pues creen en lo sagrado, el cielo, la gloria; mientras que él simplemente finge no saber -usa máscaras- para aligerar la estadía en un espacio y un tiempo que no le brindan posibilidades de libertad; de ahí la importancia del Mudito como creador, ya que la ensońación, la imaginación y la alucinación se constituirán como métodos de fuga a un mejor lugar.

Como puede observarse, el diálogo entre José Donoso y Henry James Sr., desde las diferentes relaciones transtextuales establecidas por Genette, ha permitido analizar El obsceno pájaro de la noche como una novela simbólica que da cuenta de la tragedia del hombre moderno en la figura del Mudito.

Partiendo del análisis del epígrafe, y de otros elementos paratextuales, en James y en Donoso es posible interpretar los dos textos desde una visión moderna, de manera que se produce un diálogo mediante puntos de encuentro como la conciencia de la finitud, la angustia por la inexistencia del Único, las tinieblas y el simbolismo del canto del pájaro nocturno en conjunto con el aullido del lobo.

Si bien existen conexiones, también es importante señalar la transformación crítica que realizó el escritor chileno al actualizar la cita del teólogo, ya que aunque no modificó las palabras, sí alteró el significado en tanto muestra la tragedia del hombre moderno sin posibilidad de retorno a la Edad de Oro - porque no existe para 
el protagonista-, ya que desde la literatura muestra una realidad desesperanzadora en la que el sujeto se constituye huérfano: una visión caótica del mundo de la que el hombre toma conciencia mediante la capacidad crítica propia de la modernidad; aunque, es importante enfatizar, constantemente está en búsqueda de un mejor porvenir idealizado.

\section{Bibliografía}

Achugar, Hugo, 1990, "Prólogo", en El obsceno pájaro de la noche, Biblioteca Ayacucho, Caracas.

Argullol, Rafael, 2008, El Héroe y el Único, Acantilado, Barcelona. Bocaz Leiva, María Laura, 2005, "El des-dibujamiento de la Peta Ponce: otra clave inédita de un delirio", Taller de Letras, núm. 37, Pontificia Universidad Católica de Chile, pp. 127-141.

, 2010, José Donoso, el Boom y El obsceno pájaro de la noche, Universidad de Iowa.

Donoso, José, 1970, El obsceno pájaro de la noche, Biblioteca Ayacucho, Caracas, 395 pp.

, 1971, "La novela como happening", Revista Iberoamericana, vol. XXXVII, núm. 76-77, Universidad de Pittsburgh, pp. 517-536. Chile.

, 1972, Historia personal del boom, Alfaguara, Santiago de

, 1997, "Claves de un delirio: los trazos de la memoria en la gestación de El obsceno pájaro de la noche”, en El obsceno pájaro de la noche, Alfaguara, Santiago de Chile, pp. 563-597.

Espósito, María, 2003, Diccionario Mapuche, mapuche-españoll español-mapuche, Editorial Guadal, Buenos Aires. 
Foster, Hal, 2008, Dioses prostéticos, Alfredo Brotons Muñoz (trad.), Akal, Madrid.

Genette, Gerard, 1989, Palimpsestos. La literatura en segundo grado, Celia Fernández Prieto (trad.), Taurus, Madrid.

Inostroza, Nicole, 2013, "José Donoso: perversión y espacio social en la narrativa chilena", Revista de literatura latinoamericana, vol. 1, núm. 2, Pontificia Universidad Católica de Chile, pp. 51-59.

Juan Navarro, Santiago, 2016, "Locura, monstruosidad y escritura: hacia un análisis genealógico de El obsceno pájaro de la noche”, Acta Poética, vol. 2, núm. 37, Universidad Internacional de Florida, pp. 74-86.

Kristeva, Julia, 1967, "Bajtín, la palabra, el diálogo y la novela”, en Intertextualité. Francia en el origen de un término y el desarroIlo de un concepto, Desiderio Navarro (selec. y trad.), UNEAC/ Casa de las Américas, La Habana, pp. 1-23.

Lanceros, Patxy, 1997, La herida trágica, Anthropos, Barcelona.

Larisch, Sharon, 1988, "Old Women, Orphan Girls, and Allegories of the Cave”, Comparative Literature, vol. 40, núm. 2, Universidad de Oregon, pp. 150-171.

López Pozo, Francisco, 1997, Diccionario español, griego, latín, Cultura Clásica, Córdoba.

Magnarelli, Sharon, 1981, "The Barroque, the Picaresque, and El obsceno pájaro de la noche”, Hispanic Journal, vol. 2, núm. 2, Universidad de Pensilvania, pp. 81-93.

Martin, Carmen, 2013, "Monstruos y poder en El obsceno pájaro de la noche de José Donoso", Catedral Tomada, Revista de Crítica Literaria Latinoamericana, vol. 1, núm. 1, Universidad de Ohio. Disponible en: https://catedraltomada.pitt.edu/ojs / index.php/catedraltomada/article/view/35/37 
Náter, Miguel Ángel, 2017, José Donoso: entre la Esfinge y la Quimera, Cuarto Piso, Santiago de Chile.

Paz, Octavio, 1972, El arco y la lira, Fondo de Cultura Económica, México.

,2014, "Los hijos del limo", en La casa de la presencia, Fondo de Cultura Económica, México, pp. 301-442.

Promis Ojeda, José, 1973, "La desintegración del orden en la novela de José Donoso", en Novelistas hispanoamericanos de hoy, Juan Loveluck (ed.), Taurus, Madrid, pp. 173-196.

Real Academia Española, 2006, Diccionario esencial de la lengua española, Espasa Calpe, Madrid.

Rodríguez, José Manuel, 2008, "Alguien voló sobre el nido del Bird (un estudio de los manuscritos tempranos de El obsceno pájaro de la noche)", Atenea, núm. 467, Concepción, pp.151166.

Santini, Adrián, 2001, Encierro y sustitución en El obsceno pájaro de la noche de José Donoso, RIL Editores, Santiago de Chile.

Schoennenbeck, Sebastián, 2009, "La bruja y la ruptura de un orden en El obsceno pájaro de la noche de José Donoso", Anales de literatura chilena, año 10, núm. 11, Pontificia Universidad Autónoma de Chile, pp. 161-175.

, 2017, "Sobre casas, ventanas y miradas: una cita con José Donoso y Henry James", en José Donoso. Paisajes, rutas y fugas, Editorial Orjikh, Santiago de Chile, pp. 503-722.

Soler Serrano, Joaquín, 1977, José Donoso. A fondo, Entrevista del Ministerio de Cultura, Madrid.

Ugarte Undurraga, María Francisca, 2012, "Poderosos y malignos: el mundo del servicio en El obsceno pájaro de la noche", Revista Chilena de Literatura, núm. 81, Santiago de Chile, pp. 145159. 
Verdugo Fuentes, Waldemar, 2018, "Tenemos que ser capaces (José Donoso)", en Encuentro premeditado I. Disponible en: http://entrevistas2.galeon.com/amigos779140. html 